\title{
The Meaning of Distributive Justice for Aristotle's Theory of Constitutions *
}

\author{
MANUEL KNOLL \\ Istanbul Şehir University \\ manuelknoll@sehir.edu.tr
}

\begin{abstract}
This paper examines Aristotle's theory of distributive justice and its meaning for his theory of constitutions. First, it shows that his account of constitutions in Books IV-VI of the Politics is an extension and refinement of his scheme of six constitutions in Book III. Second, it argues for the thesis that the account of

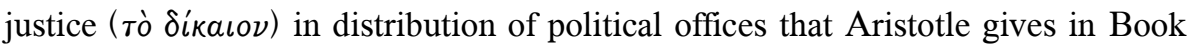

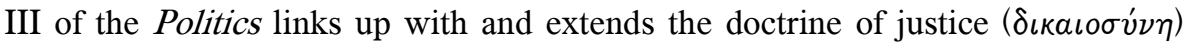
that he develops in Book V of the Nicomachean Ethics. Third, it substantiates the thesis that Aristotle understands the different forms of constitution as embodiments of different conceptions of distributive justice, and argues for the thesis that Aristotle has a clear preference for the aristocratic conception and, as a consequence, for aristocracy. Finally, it supports the thesis that the constitution of the best polis, which Aristotle outlines in Books VII and VIII of the Politics, has to be understood as a true aristocracy and not as a polity $(\pi \circ \lambda \iota \tau \in i a)$.
\end{abstract}

Key Words

Aristotle's Politics, Theory of Justice, Distributive Justice, Constitutions

Recibido: 24/03/2015 - Aceptado: 11/12/2015

The twentieth century has witnessed an impressive renaissance of Aristotle's practical philosophy. This is not only true for his virtue ethics but for his political philosophy, which is mainly a theory of constitutions ${ }^{1}$.

* For their astute and helpful comments on this paper I thank Elena Irrera and Bruno Langmeier. For considerable improvements in language and style I thank Jeremy Bell

ПН Г Н / F O N S I (2016), 57-97 
The ethical virtue that is most important for Aristotle's political philosophy is justice. In his theory of justice, he distinguishes different forms of justice, which should be applied in different spheres of the city $\left(\pi{ }^{\prime} \lambda \iota s\right)^{2}$. In the tradition of Aristotle, today we associate justice with the laws of a political community, with a fair exchange of private goods, with lawful punishment or a just distribution of public goods. Most significant for Aristotle's political philosophy are his conceptions of universal justice, which requires citizens to abide by the laws of the polis, and distributive justice, a part of particular justice. Though not usually recognized in the literature, distributive justice already plays a central role in the political philosophy which Plato develops in the Politeia and the Nomoi (cf. Knoll 2010). In contemporary political philosophy, distributive justice is still a much-debated concept: not only John Rawls's A Theory of Justice, but the theory that Michael Walzer develops in Spheres of Justice, revolve around the question of a just distribution of social goods (Rawls 1971, Walzer 1983).

This paper examines Aristotle's theory of distributive justice and its meaning for his theory of constitutions ${ }^{3}$. Such an investigation has to face some well-known philological problems and questions: does Aristotle have a coherent theory of constitutions or did his teaching develop over his lifetime, as Werner Jaeger suggested in his renowned book first published

and Stephen Snyder. And finally, thanks to David Butorac for checking my translations from Greek into English.

1 For a detailed account of this renaissance and especially of the renaissance of Aristotle's political philosophy see the voluminous dissertation GUTSCHKER 2002.

2 Aristotle develops his theory of justice in Book V of the Nicomachean Ethics, which contains the identical text as Book IV of the Eudemian Ethics, and in his Politics (especially in Book III).

3 For a fundamental critique of the legitimacy to use the term "distributive justice" for Aristotle's account of the distribution of political power see SCHüTRUMPF 2017. For my arguments against this critique see KNOLL 2011b. 
in 1923 (Jaeger 1955)? ${ }^{4}$ Is Aristotle's account of constitutions in Books IV-VI of the Politics an extension and refinement of his well-known scheme of six constitutions in Book III or does it represent a new theoretical approach? ${ }^{5}$ And on the most general level: Should we regard Aristotle's Politics as a unified work with a coherent theory or do we have to understand it as a composition of an earlier and a later treatise or as a collection of political essays that were written in different periods of his life ${ }^{6}$

This paper is not only based on but defends the weak Unitarian thesis, according to which the eight books of the Politics develop a coherent and unified theory of constitutions ${ }^{7}$. The first section gives a brief introduction to Aristotle's theory of constitutions and shows that his account of constitutions in Books IV-VI of the Politics is an extension and refinement of his scheme of six constitutions in Book III. Section two elucidates Aristotle's theory of distributive justice and the political dispute about how to fill its two formal principles with content and make them concrete. It shows that for the political culture of his time Aristotle distinguishes between four different conceptions of distributive justice.

4 For a contemporary assessment of Jaeger's hypothesis and an informative account of the history of its perception see BERTELLI 2016.

5 This is one of the central issues of my disagreement with Eckart Schütrumpf. According to Schütrumpf's genetic view, in Books IV-VI Aristotle takes a new theoretical approach in his constitutional theory. Against this view I argue that Aristotle's account of constitutions in Books IV-VI of the Politics is an expansion and refinement of his scheme of six constitutions (KNOLL 2011 b, 417-421; cf. fn. 12).

6 For an overview of the controversy between a genetic-analytic and a Unitarian view of the Politics see SCHÜTRUMPF 1980, 287-326, Rowe 1991, and BerTelli 2016.

7 According to the strong Unitarian thesis, the eight books of the Politics should be viewed as a coherent and unified work. Though many reasons and arguments for a strong Unitarian thesis can be given, our sources do not allow us to provide final and incontestable evidence for it. For my arguments for both versions of the Unitarian thesis see KNOLL 2009, 2011a, 2011b. 


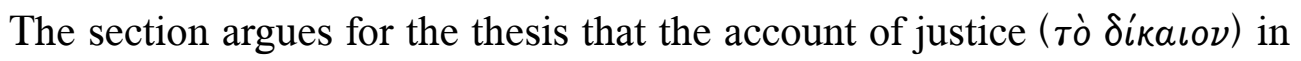
distribution of political offices which Aristotle gives in Book III of the

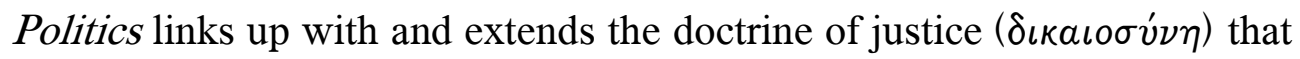
he develops in the Nicomachean Ethics. The third section substantiates the thesis that Aristotle understands the different forms of constitution as embodiments of different conceptions of distributive justice. Furthermore, it argues for the thesis that Aristotle has a clear preference for the aristocratic conception and, as a consequence, for aristocracy. The section devotes special attention to Aristotle's argumentation for the aristocratic conception of distributive justice. The final section, which is presented as a conclusion, supports the thesis that the constitution of the best polis, which Aristotle outlines in Books VII and VIII of the Politics, has to be

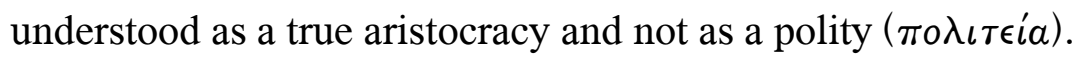

In the literature, the question of Aristotle's political preferences is a controversial issue. His well-known scheme of six constitutions provides no criterion to solve the problem of which of the three correct constitutions Aristotle prefers. In kingship, aristocracy and polity alike,

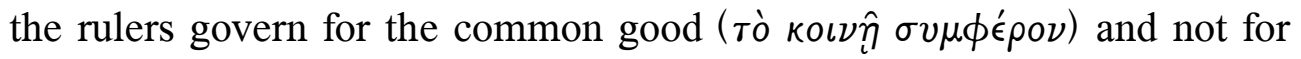
their personal advantage. In his outline of the constitution of the best polis in Books VII and VIII, Aristotle doesn't give this constitution a name. These are two important reasons why, to this day, there is a controversy regarding Aristotle's fundamental political convictions. The first line of interpretation, which prevails in the English speaking world, claims that the constitution of the best polis is an aristocracy of the best men (Barker 1959, 353; Keyt 1991; Mulgan 1991, 318; Depew 1991, 346, 362; Chuska 2000; Bates 2003, 97). The second line, which is still dominant among German scholars, understands Aristotle's "ideal constitution" as a

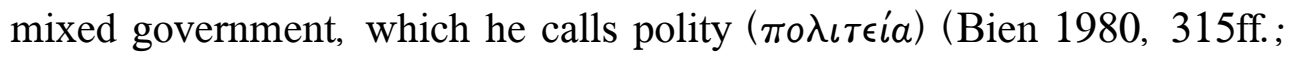
Ottmann 2001, 210; Sternberger 1984, 119, 127, 156). As a defender of "Aristotelian Social Democracy", Martha Nussbaum belongs in this line as well (1990; 2000, 109; 2001, 147). 


\section{Aristotle's theory of constitutions}

Aristotle lays out his theory of constitutions, the central subject of the Politics, in Books II through VII. Of course, for a political thinker rooted

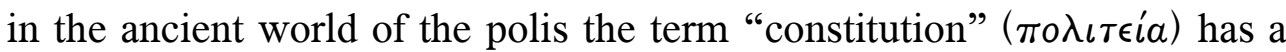
different meaning than for us today. In Book III Aristotle presents his well-known scheme of six constitutions and gives a first version of his definition of a constitution:

A constitution is the order of a polis in respect to its various offices, and especially in respect to that office which is supreme in all issues. The supreme office is everywhere the government of the polis, in fact the government is the

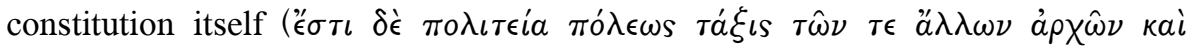

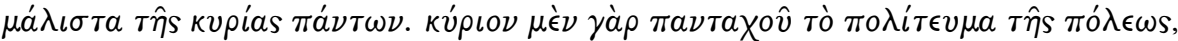

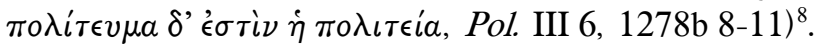

Aristotle understands a constitution as the order $(\tau a \dot{\xi} \xi \varsigma)$ which determines who rules in the political community. He even identifies the constitution with the group of the ruling citizens. According to the literal meanings of the names of the constitutions, Aristotle defines a democracy as the rule of the people $(\delta \hat{\eta} \mu o s)$, and an oligarchy as the rule of the few

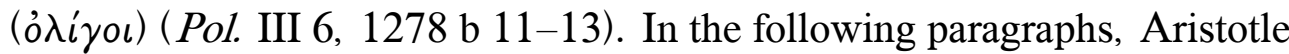
differentiates also the other forms of constitution according to the criterion of who rules in the polis. In doing so, he introduces his scheme of six constitutions, which separates the three good constitutions kingship,

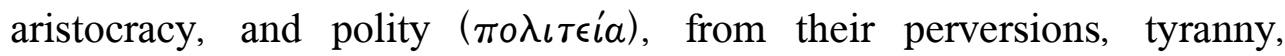
oligarchy, and democracy.

Essentially, Aristotle's constitutional scheme goes back to Plato, who develops it in the Politikos. In this dialogue, Plato's protagonist, a

8 All Greek quotes of the Politics are taken from the edition of W. D. Ross (ARISTOTELIS, 1957). 
stranger from Elea, already divides constitutions into three right and three wrong ones. The basis of both divisions is the quantitative distinction of whether one, a few, or the many rule. Like Aristotle, Plato comprehends kingship as the good government of one ruler and tyranny as the bad. Similar to his student, Plato understands aristocracy as the good government of a few rulers and oligarchy as the bad. While Aristotle calls the legitimate rule of the many "polity" ( one "democracy", Plato uses the term "democracy" for both (Pol. III 7, 1279 a 32-1279 b 10; Politikos, $302 \mathrm{c} / \mathrm{d}$ ). There are two further differences between the two constitutional schemes. First, contrary to Aristotle, Plato assumes a paradigmatic seventh constitution, in which the one or the few who have knowledge rule intelligently9. Second, Plato distinguishes the three right constitutions from the three wrong ones by means of the criterion of whether the rulers govern according to the law or against the law (Politikos, $302 \mathrm{~d} / \mathrm{e}$ ). On the contrary, Aristotle groups the six forms of constitutions according to the criterion of whether the rulers

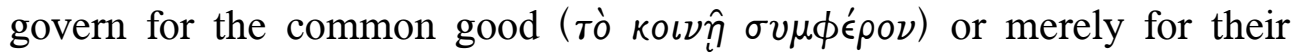
particular or personal advantage ( Pol. III 7, 1279 a 17-1279 b 10).

Aristotle distinguishes constitutions not only by means of the quantitative criterion of whether one, a few, or the many rule, and the normative-teleological criterion of whether the rulers aim at the common good or not. He differentiates constitutions also according to the specific quality of the ruler or the ruling group. Thus, Aristotle defines democracy

In the Politeia, Plato designates the best constitution, depending on whether one or more virtuous and knowledgeable persons rule, either as kingship or as aristocracy (Rep. IV, 445 d). On the contrary, in the Politikos, he understands the correct constitution, in which one or more knowledgeable people rule intelligently, as a separate seventh constitution. Plato emphasizes that the correct constitution has to be dissociated from the other constitutions as far as a God from men (297 b/c, 302 c-303 b). He conceives of the other six constitutions merely as imitations of the correct constitution, the three good ones as imitations for the better, the three bad ones as imitations for the worse (293 e, $297 \mathrm{c})$. 
as the government of the poor, oligarchy as the rule of the rich, and aristocracy as the government of the most virtuous ${ }^{10}$. Combining all three aspects of his constitutional scheme, democracy can be defined as the rule of the many poor for their own advantage, oligarchy as the rule of the few rich for their benefit, and aristocracy as the government of the few virtuous for the common good ( Pol. III 7/8, 1279 a 32-1279 b 19).

Aristotle is aware that a classification which distinguishes constitutions according to both the quantity and the quality of the rulers could lead to taxonomy problems. This would be the case if a poor minority or a rich majority ruled. For him, in political reality such cases do not happen. While in every polis there are only a few rich or virtuous citizens, the people $(\delta \hat{\eta} \mu o s)$ or the majority consists always of the poor. In political reality, the quantitative and the qualitative criterion coincide (Pol. III 8, 1279 b 20-1280 a 6; for Aristotle's account of the exception Colophon see Pol. IV 4, 1290 b 14-17).

In Books III-VI of the Politics, Aristotle extends and refines his scheme of six constitutions. He needs to do this, because the three criteria he initially offers for distinguishing constitutions are not precise enough. First, the normative-teleological criterion and its opposition between a government for the common good or for the personal advantage of the rulers is too simple. This plain opposition raises the question of how to define the common good and the advantage of the rulers, which amounts to the question about the goal or the end ( $\tau$ '́ $\lambda o s$ ) of a constitution. Concerning the three wrong constitutions, Aristotle mentions the

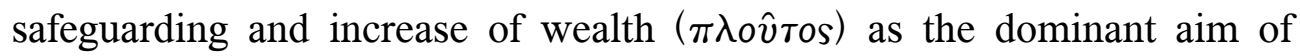

10 Already Plato distinguishes constitutions according to a qualitative criterion. $\mathrm{He}$ comprehends aristocracy and oligarchy as the rule of the rich and democracy as the rule of the poor. For him, the difference between kingship and tyranny is that the first rule is based on voluntariness and the second one on violence (Politikos, 291 e-292 a; cf. 276

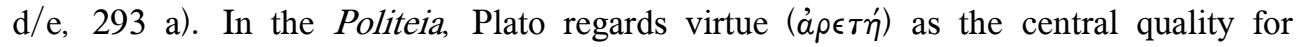
aristocracy and kingship ( Rep. IV, $445 \mathrm{~d}$ ). 
oligarchy and tyranny, and freedom ('́) $\lambda \epsilon v \theta \epsilon \rho i a)$ as the highest goal of democracy (Pol. III 9, 1280 a 25-31; Pol. V 10, 1311 a 9-10; Pol. VI 2, 1317 a 40-b 17; cf. EN VIII 12, 1160 b 12-15). How Aristotle understands the common good is disputed in the literature. Fred D. Miller, who discusses the different positions, distinguishes between individualistic and holistic interpretations of the common good, which both allow for an extreme and a moderate form ${ }^{11}$. In any case, in accordance with his ethical writings Aristotle equates the common good primarily with a good life $(\epsilon \hat{v} \zeta \hat{\eta} \nu)$ or with happiness $(\epsilon \dot{v} \delta a \iota \mu o v i a)$, the natural end of the polis.

Like the normative-teleological criterion, the quantitative and qualitative criteria are not precise enough and need to be supplemented. As a consequence, Aristotle introduces subspecies of the different constitutions. Already in Book III he presents five forms $\left(\gamma \in \dot{\epsilon} \nu \eta, \epsilon \epsilon^{\prime} \delta \eta\right)$ of kingship ${ }^{12}$. From a conceptual and logical perspective this distinction is

Miller points out: "One line of interpretation is individualistic. to promote the common advantage is to promote the ends of its individual members. The polis is happy or flourishing provided that its individual citizens are happy. [...]. Another line of interpretation is holistic: the polis resembles an organism in that it has an end which is distinct from, and superior to, the ends of its individual members" (MILLER 1995, 194; italics by Miller). Miller maintains "that the preponderance of evidence in the Politics indicates that Aristotle has a moderate-individualist position" (ibidem, 204).

According to his genetic approach, Eckart Schütrumpf maintains that in Book IV Aristotle rejects the scheme of six basic constitutions, which he presented in Book III, and displays a changed and progressed view on constitutions. For Schütrumpf, in Books IV-VI Aristotle takes a new theoretical approach. As a main reason for this interpretation Schütrumpf mentions that in these books Aristotle divides his six basic constitutions in subspecies (1980, 320-23, cf. 273; 1991, 46; 2001, 122-23). A central argument against this interpretation and in favor of the thesis that the Politics should be seen as a coherent unity is the fact that already in Book III Aristotle divides one constitution, kingship, into five subspecies. However, Schütrumpf tries to show that this division is not equivalent to Aristotle's later divisions of democracy and oligarchy in subspecies (SCHÜTRUMPF 2011, 250-257). For my arguments that Aristotle's 
necessary, because the definition of a kingship as the government of one virtuous ruler for the common advantage lacks precision. It lacks precision because it does not indicate how much political power or competences a king has. Aristotle's distinction of five kinds of kingship allows him to specify this for each form. The extremes are absolute kingship $(\pi a \mu \beta a \sigma \iota \lambda \epsilon i a)$, in which one man rules over everything, and the Spartan type of kingship, which is primarily a hereditary generalship. The remaining three forms are intermediates between these extreme forms, because in these constitutions the kings have less power and competences than in absolute kingship, but more than in Spartan kingship (Pol. III 14/15, 1284 b 35-1286 a 2).

Like the general definition of kingship, the common definitions of democracy and oligarchy as the rule of the many poor or the few rich for their own advantage have to be supplemented. Contrary to kingship, Aristotle distinguishes democracy and oligarchy not according to how much power one man has, but according to how many and which kinds of citizens participate in political power. In the first form of democracy all male citizens participate equally in government, in the second form only those who have some property and pay taxes, and in the third one only those with incontestable decent (Pol. IV 4, 1291 b 30-1292 a 7). Analogously, in the first form of oligarchy a greater number of citizens with a moderate amount of property participate in government, in the second one a lesser number with a greater amount of property, and in the third one an even lesser number with still greater property. In the fourth form of oligarchy only the very few citizens govern, who exceed everyone else by wealth and influence (Pol. IV 6, 1293 a 12-34). According to the logic of Aristotle's distinction of constitutions, a fifth form of oligarchy would pass into a form of monarchy. This shows that Aristotle's

subdivisions are essentially all equivalent extensions and refinements of his scheme of the six constitutions see KNOLL 2011 b, 417-421; cf. fn. 5. 
subdivisions correspond to each other. That Aristotle's subdivisions are equivalent can also be seen by the fact that the second form of democracy is close to the first form of oligarchy.

\section{Aristotle's theory of distributive justice}

In Book V of the Nicomachean Ethics, which contains the identical text as Book IV of the Eudemian Ethics, Aristotle develops his comprehensive theory of justice $(\delta \iota \kappa a \iota \sigma v ́ \nu \eta)^{13}$. Justice is likewise a central topic of the Politics. This is especially true for distributive justice,

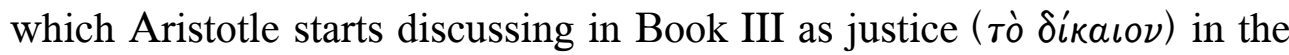
distribution of political offices (ápXás). This section substantiates the thesis that Aristotle's account of distributive justice in the Politics is an

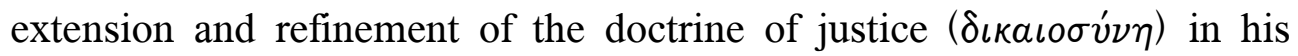
ethical writings. ${ }^{14}$ However, the central thoughts of Aristotle's theory of distributive justice are already found in Plato's Laws $^{15}$.

Almost all scholars acknowledge that the Nicomachean Ethics $(N E)$ was written by Aristotle. Concerning the Eudemian Ethics (EE), some classicists like Hellmut Flashar still doubt that Aristotle is the author $(1985,76,78)$. Most scholars today believe that the three common Books, $N E \mathrm{~V}-\mathrm{VII}$ and $E E$ IV-VI, belong to the $N E$ (BUDDENSIEK 2012, 56 (fn. 1)). These are the reasons why this paper mainly refers to the $N E$.

An opposite thesis has been recently defended by Eckart Schütrumpf. For him it is not appropriate to talk about "justice" or "distributive justice" in the Politics. Schütrumpf tries to substantiate this thesis with the fact that in Book III of the Politics Aristotle uses

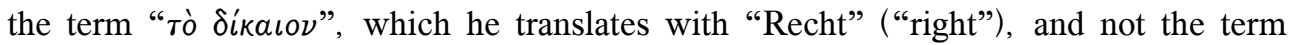

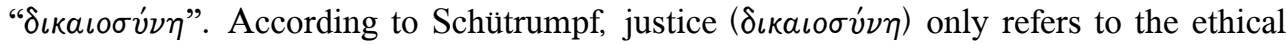

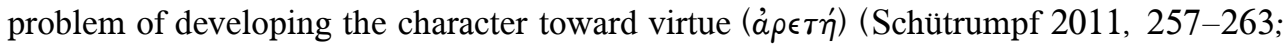
cf. my arguments against Schütrumpf's thesis (KNOLL 2011b, 414-417), cf. fn. 17. For an instructive account of the role of justice in the Politics and of Aristotle's distinction between objective and subjective justice see LISI 2017. In his paper Lisi criticizes rightfully that modern interpreters do not pay enough attention to Aristotle's important distinction between justice as an objective norm and justice as a subjective state or disposition.

15 For the reasons that substantiate this thesis see fn. 19 , fn. 21 , fn. 26 , fn. 44 , and KNOLL 2010 . 
In Book V of the Nicomachean Ethics, Aristotle distinguishes justice

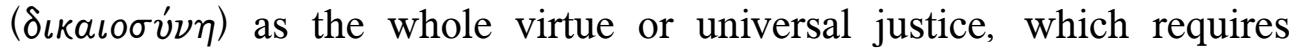
abiding by the laws of the polis, from justice as a part of virtue or

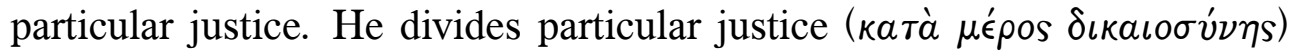
into distributive justice and rectifying justice:

One form of particular justice, and of that which is just in the corresponding sense, concerns the distribution of honour or money or other things that are divisible among those who have a share in the constitution (for in these cases it is possible for one man to have a share either equal or unequal to that of another); the

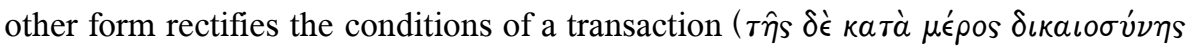

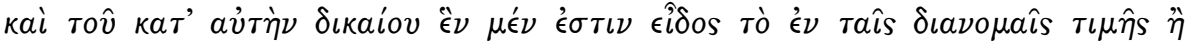

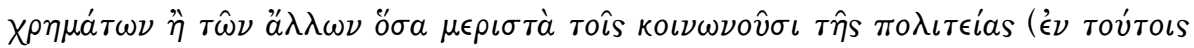

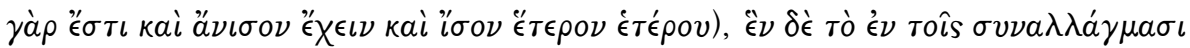

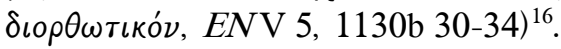

Although Aristotle mentions money and "other things" as the subject of distributive justice, this form of justice primarily concerns the just

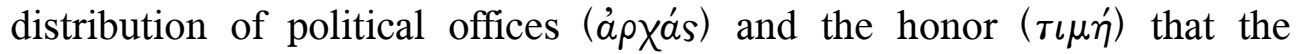
citizens can achieve by exercising them. In the Politics, Aristotle even declares that "we speak of offices as honors" (Pol. III 10, 1281 a 31). That for Aristotle distributive justice relates primarily to the distribution of political power is already apparent in the Nicomachean Ethics. Shortly after his division of particular justice into distributive justice and rectifying justice, Aristotle outlines the two formal principles of distributive justice and refers to the political dispute concerning how to fill these principles with content and make them concrete:

So the just necessarily involves at least four terms: two persons for whom it is in fact just, and two things in which it is manifested. And there is the same

16 All Greek quotes of the Nicomachean Ethics are taken from the edition of I. Bywater (ARISTOTELIS 1954). 
equality between the things as between the persons, for the things are in the same ratio to one another as the persons: if the persons are not equal, they will not get equal things. And from there quarrels and complaints originate: when either equals have and are assigned unequal shares, or unequals equal shares. This is also clear from the fact that assignments should be according to worth. For everyone agrees that what is just in distribution must be according to worth in some sense. But they do not all mean the same sort of worth: for democrats it is freedom, for supporters of oligarchy it is wealth, for others it is noble birth, and

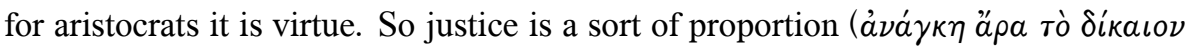

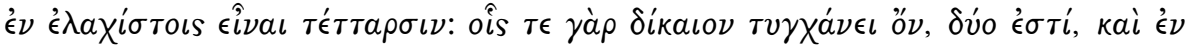

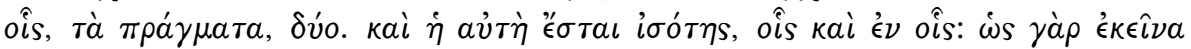

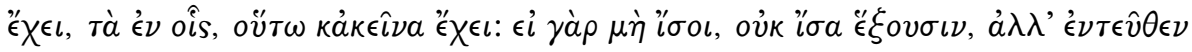

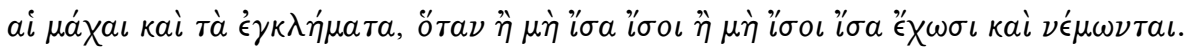

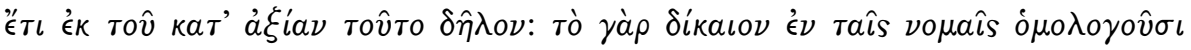

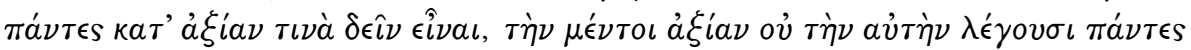

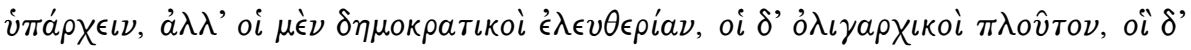

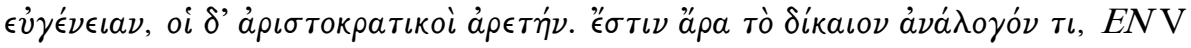
6. 1131a $18-29)^{17}$.

Distributive justice is a form of justice that is not blindfolded; it allots the goods of the polis with distinction of the persons and in view of their qualities. As different persons generally have different qualities, they usually get allotted unequal shares. In a just distribution, these shares should be bestowed on the persons in proportion to their different qualities, or as Aristotle puts it, in proportion to their unequal worth or merit $\left(\dot{a} \xi^{\prime} a\right)^{18}$. In a just distribution everyone gets allotted equal shares in proportion to his unequal worth or merit. Like Plato, Aristotle calls this

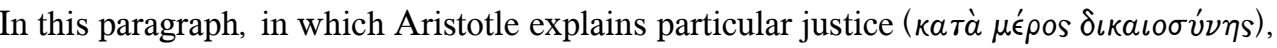

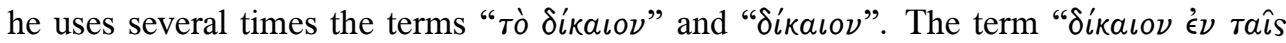
$\nu o \mu a \hat{\imath}$ " can be translated as "just in distribution" and as well as "justice in distribution".

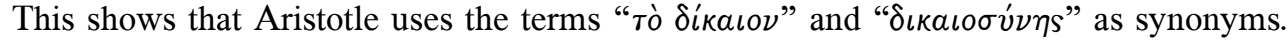

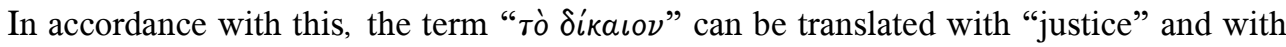
"right" or "Recht" (cf. fn. 14).

18 Only in a few English editions of the Nicomachean Ethics and the Politics the term "á $\xi i a "$ is translated with "worth". Usually it is rendered with "merit". 
form of equality, which he opposes to "numeric" or "arithmetic" equality, "proportional" or "geometrical" equality (ENV 6, 1131 a 29 ff. $)^{19}$. For Aristotle, a distribution to citizens is just if the public goods are allotted according to proportional or geometrical equality.

The above quoted paragraph from the Nicomachean Ethics contains two formal principles of distributive justice. The first principle establishes that a just distribution is one according to worth ( $\left.\kappa a \tau^{\prime} \dot{a} \xi \xi^{\prime} a \nu\right)$. The second principle, which also refers to the relation between the persons who have claims, determines that only equals should get equal shares, while unequals should be allotted unequal shares. The first principle can be phrased "To everyone in proportion to his worth or rank", the second one "Equal shares to equals, unequal shares to unequals"20.

Aristotle observes that there is a consensus among citizens that justice in distribution "must be according to worth in some sense" 21 . But at the same time he reports a substantial disagreement about the criterion or standard, which is appropriate in order to measure worth ( $\left.\dot{a}^{\xi} i a\right)$. This disagreement exists among citizens in so far as they have different political

In the Laws, in which he already develops the main elements of Aristotle's theory of distributive justice, Plato distinguishes between two concepts of equality. One kind of equality he calls "equality according to measure, weight and number", and the other one the "most genuine" and "best" equality. This sort of equality, which for him is inextricably linked to political and distributive justice, allots more to the greater - more virtuous and educated - person, and less to the inferior one (VI, $757 \mathrm{a}-\mathrm{e}$ ). In the Gorgias Plato calls this form of equality "geometrical equality" (508 a, cf. 490 b-e). Cf. fn. 26 and fn. 44.

The principle "To everyone in proportion to his worth or rank" is more appropriate for Aristotle's political thought than the principle "To each his own", which in German literature on Aristotle is usually regarded as the formula for distributive justice (ENGISCH 1971, 159; HAACKE 1994, 28; SALOMON 1937, 26; TRUDE 1955, 108). The principles "To everyone in proportion to his worth" and "To everyone in proportion to his rank" are equivalent (cf. HAACKE 1994, 28; RICKERT 1997, 27).

21 Cf. Pol. V I, 1301 b 35-36. In the Laws, Plato already declares that candidates for political offices should be elected or rejected "according to their worth" (VI, $751 \mathrm{~d}$ ). 
convictions. Aristotle mentions four groups with fundamentally different political convictions, which go along with four different standards of worth. The democrats favor "freedom (' $\left.\epsilon^{\prime} \in v \theta \epsilon \rho i a\right)$ " as the criterion of worth, the supporters of oligarchy "wealth ( $\pi \lambda \circ \hat{v} \tau o s)$ ", the aristocrats "virtue $\left(\dot{a} \rho \epsilon \tau \eta^{\prime}\right)$ ", and an unnamed fourth group "noble birth $(\epsilon \dot{v} \gamma \in \dot{\prime} \in \iota a)$ ". It is important to notice that for Aristotle the true aristocrats (áрıтократькоі) are those who hold "virtue" to be the appropriate standard of worth and not those who favor "noble birth". While the criteria "wealth", "virtue", and "noble birth" allow a gradation of "more" and "less", people are either free as citizens or - Aristotle's contrast to freedom - they are slaves, foreigners or resident aliens ${ }^{22}$.

For the political culture of his time Aristotle distinguishes between four different ways to fill the two formal principles of distributive justice with content and make them concrete. In accordance with this he discriminates four different conceptions of distributive justice: the democratic, the oligarchic and the aristocratic conception, and an undesignated fourth conception $^{23}$. Each of the two principles thus can be phrased in four different ways: "To everyone in proportion to his wealth, freedom, virtue or noble birth", and: "Equal shares only to persons equally wealthy, free, virtuous, or with equally good ancestors".

Cf. KEYT 1991, 243-44. Keyt doesn’t explicitly mention resident aliens.

Applying a distinction which John Rawls introduces in A Theory of Justice, David Keyt explains that "we can distinguish the concept of distributive justice from the various conceptions of it". Keyt understands the different conceptions as interpretations of the one principle of distributive justice (KEYT 1991, 242-43, italics by D.K., cf. RAWLS 1971, 5-6, and Keyt's fn. 16 to the ultimately Aristotelian roots of Rawls's distinction). Less appropriate, Fred D. Miller talks about a "dispute among different theories of justice: oligarchic justice, democratic justice, and aristocratic justice. At issue are rights within the political community" (MILLER 1995, 124; italics by M.K.). Miller's expression "different theories of justice" is problematic, because it suggests that the different conceptions of distributive justice have little or nothing in common, which is not the case. 
In the Politics, Aristotle refers two times to the short account of distributive justice that he gave in the Nicomachean Ethics (Pol. III 9, 1280 a 16-25; Pol. III 12, 1282 b $18-23)^{24}$. Both references are located in Book III, which many scholars identify for good reasons as the centre of the whole Politics ${ }^{25}$. In Book III, Aristotle takes up the issue of the political dispute about the appropriate standard of worth and gives reasons for his own position. He concedes that in the political quarrel over how political offices should be distributed, freedom, wealth, noble birth, and virtue can be regarded with some right and for some reasons as justified claims. But none of the claims of the four political convictions in question are "absolutely justified" ( Pol. III 13, 1283 a 29-31). Aristotle is not the first thinker who distinguishes and analyses competing reasons that support claims to political power. In the Laws, Plato already distinguishes seven, or rather eight, contradictory and competing claims (á $\xi \iota \omega \mu a \tau a)$ used to justify ruling political communities and families ${ }^{26}$.

In the political dispute about the just distribution of offices and the appropriate standard of worth all four political groups or parties can put forward some arguments. The supporters of an oligarchic conception of distributive justice, which Aristotle equates with the rich, argue that they pay more taxes, that they are "usually more reliable in matters of

These two references are usually, as Olof Gigon and Franz Susemihl state in their commentaries on the Politics, related to Book V 6 of the Nicomachean Ethics (ARISTOTELES 1965, 289; ARISTOTELES 1973, 306, 311).

David Keyt calls Book III "the philosophical core of the entire treatise" (KEYT 1991, 247). William L. Newman understands Book III as ,the centre round which the whole treatise is grouped" (NEWMAN 1887-1902, II, XXXI). The interpretation that Book III is the centre of the whole Politics can be substantiated as well by the cross-references (cf. KEYT/MILLER 1991, 4).

For Plato's distinction and list of seven reasons for claims see Laws III, 689 a-690 d. Though the claim of the rich citizens to share in the offices and honors in proportion to their wealth is not part of Plato's list, he mentions it in Book V as an eighth claim (Laws $\mathrm{V}, 744 \mathrm{~b}-\mathrm{c})$. 
contract" and that they "have a larger share of the land", which is "to the benefit of the public" (Pol. III 9, 1280 a 25-31; Pol. III 13, 1283 a 3133). Because of these merits they hold an unequal share in political power to be just, and claim that an oligarchy, in which the offices are distributed in proportion to wealth, is the appropriate constitution. Aristotle criticizes this position, stating that one cannot derive conclusively from the single particular inequality of wealth a general inequality that could justify an oligarchic constitution. The argument of the supporters of oligarchy would be convincing if the end of the polis were wealth. But for Aristotle this is not the true goal of a political community (Pol. III 9, 1280 a 22-31; Pol.

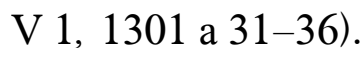

The adherents of a democratic conception of distributive justice argue that all male citizens are equal, because they are all born as free men. Because of that they hold it to be just if both the poor and the rich get an equal share in political power, and claim that a democracy is the appropriate constitution. Aristotle criticizes this position, stating that one cannot derive conclusively from the single particular equality of freedom a general equality that could justify a democratic constitution ( Pol. III 9, 1280 a 22-31; Pol. V 1, 1301 a 28-36). The argument of the democrats would be convincing if the true goal of the polis were freedom, but this an idea which Aristotle rejects.

In the democracies of Aristotle's time not only slaves and foreigners, but women and young men were excluded from political participation. The democratic method of distributing the majority of offices was a distribution for a short period by lot. The consequence was an equal chance for all male citizens to participate in political power, which led to a system "of all ruling over each, and of each over all in turn" (Pol. VI 2, $1317 \mathrm{~b} \mathrm{18}-20)$. It is worth noticing that the account of the democratic conception of distributive justice, which Aristotle gives in the Nicomachean Ethics, differs in an important aspect from the one he gives in the Politics. In the Ethics he equates democratic justice with a 
distribution according to worth ( $\kappa a \tau^{\prime}$ á $\left.\xi^{\prime} a \nu\right)$, which the democrats measure with the standard "freedom". In the Politics he identifies democratic justice with equality according to number, which he opposes

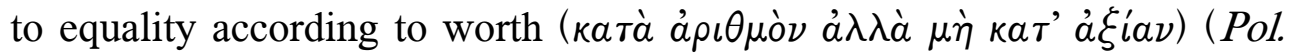
VI 2, 1317 b 4, cf. 1318 a 3-10). While in the Nicomachean Ethics Aristotle seems to use "worth (á)ia)" as a generic term or an open concept which can assume different meanings, in the Politics he uses it in a non-egalitarian sense pointing to the idea of an unequal rank, merit or desert of citizens.

Contrary to supporters of both democratic and oligarchic conceptions of distributive justice, the members of the good families refer to their noble birth $\left(\epsilon \dot{v} \gamma^{\prime} \in \in \iota l a\right)$. They argue that they are citizens to a greater degree than those of low birth, that good birth is honored in every community, and that descendants of good parents are likely to be better than children of the low-born, because noble birth is the virtue of the family. With these arguments the better-born claim that it is justified that they get a bigger share in political power than the low-born (Pol. III 13, 1283 a 33-37).

3. Distributive justice and constitutions: Aristotle's arguments for the aristocratic conception of distributive justice and for aristocracy

In a first step, this section substantiates the thesis that Aristotle understands the different forms of constitution, with the exception of tyranny, as embodiments of different conceptions of distributive justice. In a second step, the section argues for the thesis that in the political dispute among the supporters of four conceptions of distributive justice Aristotle has a clear preference for the aristocratic conception ${ }^{27}$. Taken together,

An opposite thesis is central for Dolf Sternberger's interpretation of Aristotle's fundamental political convictions. Sternberger claims that Aristotle differs "considerably" from Plato, because Aristotle values democratic equality and justice "equally" as oligarchic and aristocratic equality and justice (STERNBERGER 1984, 13031, 139, 154; cf. fn. 19 and fn. 44). 
these two theses yield a third one: Because Aristotle has a preference for the aristocratic conception, he must likewise have a preference for aristocracy.

The above given reconstruction of the arguments of the well-born, the democrats, and the supporters of oligarchy shows that each conception of distributive justice is linked with its corresponding constitution. To advocate the distribution of political offices in proportion to wealth is the same as to support oligarchy. To claim that every free-born male citizen should get an equal share in political power is identical with the endorsement of democracy. And likewise, "the distribution of honors according to virtue ( $\alpha a \tau^{\prime} a \rho \epsilon \tau \eta^{\prime} \nu$ ) seems to be the most characteristic trait of aristocracy; for virtue is the defining criterion of aristocracy, as wealth is the criterion for oligarchy, and free birth of democracy" (Pol. IV 8, 1294 a 9-11). The political dispute over the just distribution of the offices and the appropriate standard of worth amounts to a quarrel over the appropriate constitution of the polis.

In Athens, the dispute of political parties over the right constitution of the polis broke out long before Aristotle's birth ${ }^{28}$. This dispute turned into a violent fight during the Peloponnesian War, which was led from 431 until $404 \mathrm{BC}$ between Athens and Sparta and their respective allies. During this horrific war, civil wars broke out in several cities, in which Athens endorsed the democratic and Sparta the anti-democratic forces. Like the defection of one polis from their ally, a civil war often led to a change in constitution. While Athens introduced democracy, Sparta

In The Constitution of Athens, Aristotle (or some other author) reports about Athens in the early $6^{\text {th }}$ century BC: "The parties at this time were three in number. First there was the party of the Shore, led by Megacles the son of Alcmeon, which was considered to aim at a moderate form of government; then there were the men of the Plain, who desired an oligarchy and were led by Lycurgus; and thirdly there were the men of the Highlands, at the head of whom was Pisistratus, who was looked on as an extreme democrat" (ARISTOTLE, 1991, § 13, 11-12). 
substituted democracy with a constitution that they called an "oligarchy", in which only a part of the people held political power ${ }^{29}$.

In Book V of the Politics, Aristotle examines the change $\left(\mu \epsilon \tau a \beta o \lambda \eta^{\prime}\right)$ of constitutions and in particular why they decay and how they can be preserved. In the important first chapter he declares that democracy and oligarchy are the prevailing constitutions of his time. In view of these two constitutions he explains the general causes and motives for sedition and revolution $(\sigma \tau a \dot{\sigma} \sigma \varsigma)$. His account is based on his theory of distributive justice. He even holds that democracy and oligarchy originate from the opposing conceptions of distributive justice of their supporters (Pol. V I, 1301 a 25-32). From these opposing conceptions the citizens of competing political parties also derive their irreconcilable judgments of whether an equal or unequal distribution of political power is just or unjust. Therefore, the opposing conceptions are, in the end, the reason why democracies and oligarchies are often not stable and cannot be preserved. The rich citizens strive to overthrow democracies, because they hold an equal distribution of political power to be unjust. Sedition in oligarchies originates because the poor citizens think their exclusion from political life is unjust and because they demand an equal participation in government ( Pol. V I, 1301 a 32-1302 a 13) ${ }^{30}$. For Aristotle, the general cause or motive for sedition and revolution is that citizens are outraged and get angry when they perceive power relations to be unjust, and therefore want to change them ${ }^{31}$. This cause or motive concerns the inner

THUKYDIDES 2002, III, 82, 206; BLEICKEN 1994, 58-59; cf. GEHRKE 1985, 356, and BLEICKEN 1994, 59). After the Peloponnesian War, some more bloody overthrows happened in Greece, for example in Thebes and in Thessalia (GEHRKE 1985, 352).

In Book V, Aristotle declares several times that the cause for political overthrow in democracies and oligarchies is that the people or the rich think that the distribution of political rights is unjust (1302 a 22-32, 1303 b 3-7, 1316 a 39-1316 b 3).

Ronald Polansky points out: "Since the disposition fostering change or sedition is ultimately the sense of injustice in distribution in the community, this must be the most general of all the causes operative in change" (Polansky 1991, 335). In line with 
state of the revolutionaries that is brought into being by their sense of justice. In the end, the human sense of justice which enables man to have perceptions of good and bad, of just and unjust, is the "anthropological" basis of all different conceptions of distributive justice ${ }^{32}$.

As several scholars have pointed out, Aristotle understands the different forms of constitution, except tyranny, as embodiments of different conceptions of distributive justice ${ }^{33}$. In the Eudemian Ethics, Aristotle declares that "all constitutions are a particular form of justice; for they are communities, and every community is held together by justice ( $a i$

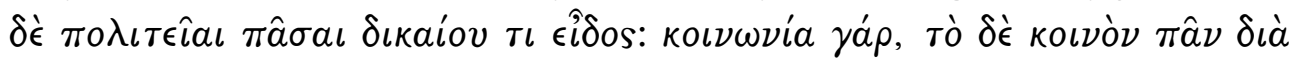

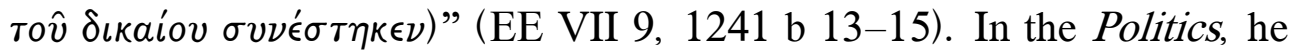
explains an important aspect of how justice holds the political community together. A constitution is not only the order which determines to whom

Polansky, Hans-Joachim Gehrke pronounces: "In der Tat ist der entscheidende Gesichtspunkt das Empfinden der ungerechten Behandlung durch das Vorherrschen differenter Gleichheitsvorstellungen. Man fühlt sich zurückgesetzt und benachteiligt, in seinem Recht und Anspruch verletzt. Es unterliegt keinem Zweifel, daß Aristoteles hier ein ganz wesentliches Movens der 'Aufsässigkeit' erarbeitet hat” (GEHRKE 2001, 143).

In a famous paragraph Aristotle explains: "Contrary to the other living beings, it is peculiar to man that he alone has perception $\left(a \iota^{\prime} \sigma \theta \eta \sigma \iota \nu\right.$ ' $\left.\chi \chi \iota \nu\right)$ of the good and bad, of the just and unjust, and of other similar qualities. Community in these things makes a household and a polis" (Pol. I 2, 1253 a 15-18). In view of this paragraph, John Rawls states: "Aristotle remarks that it is a peculiarity of men that they possess a sense of the just and the unjust and that their sharing a common understanding of justice makes a polis" (RAWLS 1971, §39, 234). For Rawls, together with the human capability of having a conception of ones good, the capability for a sense of justice is the "basis of equality" of "human beings as moral persons" (ibidem, § 4, 19; cf. § 77, 505).

Richard Mulgan explains: "Different constitutions embody different conceptions of justice with differing criteria of how honours and other public goods should be distributed" (MULGAN 1991, 310). In line with this Fred D. Miller pronounces "that the constitution is in some manner identical with justice (in the sense of being the embodiment of justice)" (MILler 1991, 299, cf. Miller 1995, 79). Analogously, David Keyt points outs that "a constitution is primarily a kind of distributive justice" (KEYT 1991, 238). 
the political power is allotted in the polis, but ethically justifies this distribution through a conception of distributive justice inextricably linked to it. Furthermore, a constitution establishes what the final or dominant goal of the political community is. The question of the goal of the polis is an ethical question, because it mainly revolves around the decision of what a political community and its rulers hold to be a good life and what values it holds to be important. In Book IV of the Politics, Aristotle gives a second and extended version of his definition of a constitution which includes these two ethical aspects:

A constitution is the order of a polis in respect to its various offices and the questions of how they are distributed, what the supreme power of the polis is, and

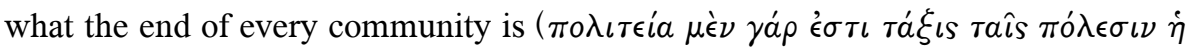

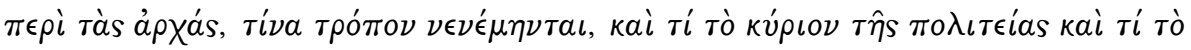

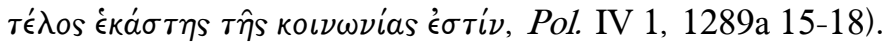

Aristotle discusses both the ethical questions of the just distribution of the political offices and of the goal of the polis in the chapters in Book III, which follow his first definition of a constitution. This strongly suggests the interpretation that he phrases a second definition in order to include the results he gained in Book III. This is an argument for the unity of the Politics. First, it shows that there is no rupture between Books III and IV, as the supporters of the genetic-analytic interpretation of the Politics suggest $^{34}$. Second, it indicates that the subjects and arguments of the Politics are not only coherent and consistent, but build on each other in such a way that later parts implicitly or explicitly refer back to earlier

34 For Werner Jaeger, the Politics is divided in an early "Urpolitik" (Books II, III, VII, and VIII), which contains Aristotle's "speculative outline", and the "empirical books" IVVI, that were supposedly written later (JAEGER 1955, 275-282). According to Eckart Schütrumpf, Book III is an early precursor to the discussions in Book IV, and a treatise that has not been completely preserved or that has never been finished (SCHÜTRUMPF 1980, 273). 
parts, which they presuppose, continue, distinguish, or supplement ${ }^{35}$. Both points can be further substantiated by section one of this paper, which demonstrated that Aristotle's account of constitutions in Books IV$\mathrm{VI}$ is essentially an extension and refinement of his scheme of six constitutions in Book III. The introduction of subspecies of the different constitutions already begins in Book III, which distinguishes five forms of kingship ${ }^{36}$.

A constitution establishes what the goal or end of a political community is. As has already been pointed out, in Book III Aristotle assesses three constitutions as wrong because they are forms of government structured for the advantage of the rulers and not for the common good. In oligarchy and tyranny, the end of the rulers and thus the polis is to safeguard and increase wealth, in democracy the highest goal is the realization of freedom. According to Aristotle, democratic freedom means that everyone can live how he wants. Aristotle makes clear that neither freedom nor wealth can be regarded as the true ends of a polis ( Pol. III 9, 1280 a 22-31; Pol. V 9, 1310 a 28-36, cf. Pol. VI 2, 1317 b 10-13).

After he rejected freedom and wealth as candidates for the true goal of the polis, Aristotle mentions several ends and shows that these cannot be regarded as the specific or highest goals of the political community. He brings up bare life or survival, mutual defense against injury, trade and mutual intercourse or advantage, and mutual protection against injustice and damages as possible ends of a polis (Pol. III 9, 1280 a 31-1280 b 5). Against such conceptions of the goal of the political community Aristotle argues that trade agreements, treaties for mutual defense, and other forms of alliance also exist between peoples and thus cannot be regarded as the characteristic or specific end of a polis. The goals to mutually protect each other, to not harm each other, or to do trade are only

For a compilation of examples of how the subjects and arguments of the Politics build on each other see KNOLL 2011 b, 413-14; cf. fn. 47.

Cf. fn. 12. 
pre-conditions that must be present before a polis can exist; but the presence of all these conditions is not enough to make a polis. What constitutes a polis is an association of households and clans in the good life $(\epsilon \hat{v} \zeta \hat{\eta} \nu)$, in order to achieve a perfect and self-sufficient existence. [...] The goal ( $\left.\tau \epsilon^{\prime} \lambda o s\right)$ of the polis is the good life, and these things are means to that end. And a polis is an association of clans and villages in a perfect and self-sufficient existence, which in our view constitutes

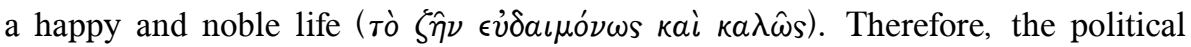
communities must be considered to exist for the sake of good actions $(\pi \rho a ́$ $\xi \epsilon \omega \nu)$, and not for the sake of bare social life. Hence, those who contribute most to such an association have a greater share in the polis then those who are their equals or superiors in freedom or decent but not their equals in political virtue ( $\dot{a} \rho \epsilon \dot{\eta} \nu)$, or than those who surpass them in wealth but are surpassed by them in virtue (Pol. III 9, 1280b 31-35; 1280b 39-1281 a 8).

The supreme goal of the polis is the good and happy life. Aristotle states this conviction in the first paragraphs of the Nicomachean Ethics, in

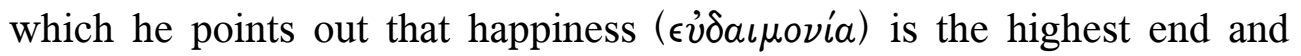
supreme good which man can achieve through his actions ${ }^{37}$. Aristotle's definition of the supreme goal of the polis is a premise of the argument that he gives in order to substantiate his own preference in the political dispute about how political offices and honors should be distributed ${ }^{38}$. The paragraph cited above gives a short version of this argument and mentions once more the four competing reasons for political claims that were common in the political culture of Aristotle's time: freedom, wealth, noble birth and virtue.

Aristotle's argument for his political preference is part of his general theory of what constitutes a just distribution. Usually in a distribution of goods there are different people who have claims and who advance

In the beginning of the Nicomachean Ethics, Aristotle states that happiness ( $\epsilon \dot{v} \delta a \iota \mu o v i a)$ as the supreme of all practical goods is related to political science (ENI 2, 1094 b 7-10). For an interpretation of Aristotle's argument that is partly different and partly similar than the one given above see KEYT 1991, 250-259. 
different and competing reasons in order to justify their claims. According to Aristotle's theory, the disputed question of which reason for political claims is most justified in a distribution can be decided in regard to the goal of this distribution. A reason for a justified claim must not only have a factual connection to the goal of the distribution but must also contribute substantially to reaching it.

A first illustration of this general theory can be seen in Aristotle's critique of the oligarchic and the democratic conceptions of distributive justice (Pol. III 9, 1280 a 22-31). The supporters of oligarchy claim a greater share in the polis, in offices and honor, in proportion to their greater wealth, which is their claim's justification. If the goal of the polis were property or wealth, the supporters of oligarchy would have a strong argument. As an instructive analogy to the polis and the competing claims of the rich and the poor Aristotle brings up an imaginary financial partnership of two men with a capital of 100 talents in which one man contributed only one talent and the other one 99 talents. It is obvious that in such a partnership the man who only put in one talent would only have a share in the whole capital and in the interest it generates in proportion to his contribution and thus a much smaller share than the man who put in 99 talents. As the only goal of a financial partnership is an increase in wealth, such extremely unequal shares are justified. But for Aristotle, the polis is neither a financial partnership nor is its goal an increase in wealth or property.

This paragraph of the Politics is not well-elaborated, but it suggests that Aristotle has a similar critique of the democratic conception of distributive justice in mind, whose supporters he criticizes alike for not being able to see that the justified claims they can make are very limited. If the goal of the polis were the realization of freedom, all free men, the rich and the poor alike, could make an equal contribution to reach this goal and thus have an equal share in the political community. But the polis is not a 
partnership for the goal to realize ones freedom (Pol. III 9, 1280 a 2531).

A second illustration of Aristotle's general theory is his example of a just distribution of flutes ${ }^{39}$. If flutes are distributed in a just way, the person who is distinguished through the capability of outstanding flutepaying should get the best flute ${ }^{40}$. To be sure, alternative reasons for claims like noble birth, beauty, or wealth have a higher rank in the general order of goods than the capability of flute-paying. But they have no factual connection to the goal of good flute-paying and they do not contribute anything to reach it. This is why they are arbitrary and irrelevant standards in a just distribution of flutes. With his example of a just distribution of flutes Aristotle makes clear that offices and honors should not be allotted according to superiority in any good whatsoever. There are goods like height or the ability to run fast which are irrelevant in a just distribution of offices and honors, because they have no factual connection to the goal of the polis and do not contribute anything to the attainment of it. Furthermore, a distribution according to superiority in any good whatsoever would presuppose that every good is comparable with any other, which is impossible in regard to the heterogeneity and incommensurability of the mentioned goods ( Pol. III 12, 1282 b 23-1283 a 11).

Aristotle concedes that the standards of freedom and wealth have some claim in the political distribution of offices and honors. A polis that

Some chapters before Aristotle introduces his example of the distribution of flutes, he declares that "the ruled correspond to the flute-maker, the ruler to the flute-player who uses the instrument" (Pol. III 4, 1277 b 29-30). Like flute-makers allot flutes to fluteplayers, the ruled distribute political power to the rulers.

40 For Martha Nussbaum's interpretation of Aristotle's example of a just distribution of flutes see NUSSBAUM 1990, 171. According to Nussbaum's interpretation of his theory of distributive justice, Aristotle holds a capability for a certain function to be the "morally relevant criterion" for the distribution of "the necessary material conditions" to perform this function (ibidem). 
consisted only of slaves would not be able to exist. The same is true for a polis made up of only poor people. Such a polis would have no income in taxes and, as such, no financial means for public affairs. This demonstrates that both the poor and the rich citizens together with their qualities make an indispensable contribution to the existence of the polis. Therefore, they can claim some share in political participation. However, in a just distribution of offices and honors, Aristotle holds political virtue to be the standard of worth that is most justified ${ }^{41}$.

The first step of Aristotle's argumentation for the aristocratic conception of distributive justice is to substantiate the thesis that the specific goal of the polis is the good and happy life, as opposed to survival, wealth, freedom, or something else. While people agree that flutes should be distributed for the end of good flute playing, there is no consensus among them about the true end of the polis. As a second step he establishes his general theory of distributive justice, according to which a justified claim in a distribution must not only have a factual connection to the goal of this distribution but must also contribute substantially to reaching it. The third and final step is to show that political virtue contributes much more to a good and happy life than do freedom, wealth, or noble birth. The conclusion of these steps is that the aristocratic conception of distributive justice can claim by far better reasons than the other three conceptions, which shows that Aristotle has a clear preference for it.

Considering the competing standards noble birth, freedom, wealth, justice $(\delta \iota \kappa a \iota \sigma \sigma v v \eta)$ and political virtue $\left(\pi \circ \lambda \iota \tau \iota \kappa \dot{\eta} \alpha \rho \in \tau \eta^{\prime}\right)^{42}$, Aristotle phrases this conclusion as follows:

41 The paragraph above shows that Ada Neschke-Hentschke's interpretation that "only" political virtue can advance a claim for rule is too exclusive and too rigid (NESCHKEHENTSCHKE 2012, 115).

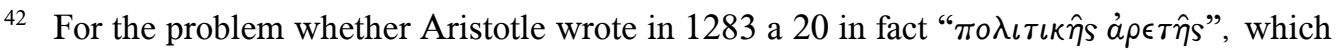

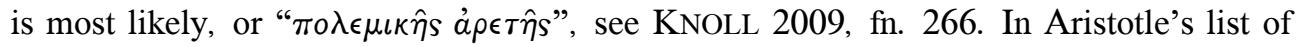


In view of the existence of the polis, it would seem that all, or at least some, of these controversial claims are justified; but in regard to the good life education and

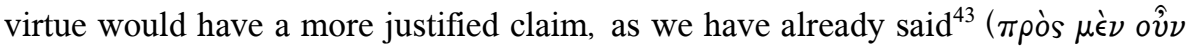

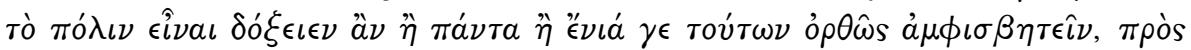

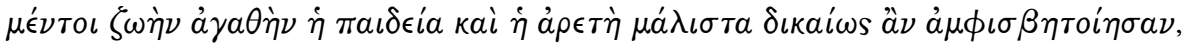

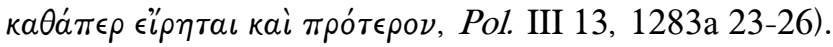

Like Plato, Aristotle holds "education $(\pi a \iota \delta \in i a)$ " and "virtue ( $\left.a \rho \in \tau \eta^{\prime}\right)$ " to be the appropriate standard of worth in a just distribution of offices and honors ${ }^{44}$. In his statement, "education" and "virtue" should not be apprehended as rivaling claims. Rather, education should be understood as the formation of the soul $\left(\psi v \times \eta^{\prime}\right)$ that leads to the ethical virtues, the virtues of the character ${ }^{45}$. The most important ethical virtue is justice as a trait of character or disposition $(\stackrel{\bullet}{\epsilon} \xi \iota s)$. Starting at an early age, education has to form the activities and thereby the habits in order to produce a virtuous character. For Aristotle, education should not only focus on subjective justice but also on other ethical virtues like courage ( $a \nu \delta \rho \epsilon i a)$ and temperance ( $\sigma \omega \phi \rho o \sigma v ́ v \eta)$ ( $E N$ II 1, 1103 a 31-1103 b 25). Together with the intellectual virtue named prudence ( $\phi \rho o ́ \nu \eta \sigma \iota)$, these ethical virtues constitute what Aristotle calls political virtue $\left(\pi \circ \lambda \iota \tau \iota \kappa \dot{\eta} a \dot{\rho} \epsilon \tau \eta^{\prime}\right)$. Already in Chapter 4 of Book III he mentions prudence ( $\phi \rho o ́ \nu \eta \sigma \iota s)$ as the virtue peculiar to a good ruler (Pol. III 4, 1277 a 14-15; cf. Elm 1996).

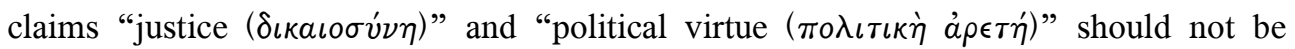
understood as rivaling claims, as for Aristotle justice is a part of political virtue. Cf. Pol. III 9, 1281 a $7-8$.

43 This statement refers back to the short version of Aristotle's argument in Pol. III 9, 1280 b 39-1281 a 8.

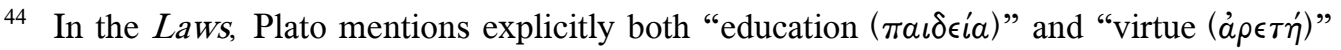
as the relevant standard for the "most genuine" and "best" form of political justice and equality (VI, 757 c); cf. KNOLL 2010, and fn. 19.

Cf. PATt 2002, 78. 
For Aristotle, political virtue is the most justified reason for claims in a distribution of offices and honors ${ }^{46}$.

For Aristotle, political virtue contributes substantially to reaching the goal of the polis, the good and happy life. In order to answer the question of how Aristotle conceives of this contribution, it is necessary to ask how he conceives of a good and happy life. According to the central definition

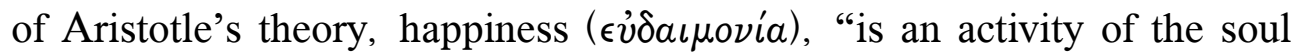
according to virtue ( $\left.\kappa a \tau^{\prime} \dot{a} \rho \in \tau \eta^{\prime} \nu\right)$ " (EN I 6, 1098 a 16-17). Human beings can live a good and happy life if they develop and practice their ethical and intellectual virtues in two forms of life. As citizens, they can practice the combination of prudence ( $\phi \rho o ́ \nu \eta \sigma \iota s)$ and ethical virtues in a political life. As scientists or philosophers, they can practice their intellectual virtues wisdom ( $\sigma \circ \phi i a)$ as a combination of science $\left(\dot{\epsilon} \pi \iota \sigma \tau \eta^{\prime} \mu \eta\right)$ and intuition ( $\nu$ ovs) - in a life of contemplation (ENI 3, 1095 b 14-1096 a 5; ENI 13, 1103 a 1-7; ENVI 3, 1139 b 16-17; EN VI 7, 1141 a 19).

It is not difficult to see how political virtue contributes substantially to reaching the good life, the goal of the polis. To practice political virtue as a citizen is identical with good actions and a political life. In an active political life a citizen carries out virtuous actions for his polis in the assembly, the council, the law-courts, or in war. For Aristotle, an active political life, in which citizens deliberate, govern, and shape the polis, counts as a good and happy life. Such a life aims at honor, and, as an even higher end, at virtue (ENI 3, 1095 b 22-31). Furthermore, it depends on the political virtue of the citizens whether a polis flourishes or perishes, whether it can keep its self-sufficient existence or not, and whether its constitution remains stable or faces civil war and sedition. If politically virtuous citizens maintain the stability of the political order and ensure that

See for a similar interpretation of Aristotle's evaluation of the role of political virtue GORDON 2007, 145, 154, and SCHüTRUMPF 1980, 146. According to Ada NeschkeHentschke, for Aristotle political virtue is composed out of prudence ("der praktischen Klugheit") and just ethos ("dem gerechten Ethos") (NESCHKE-HENTSCHKE 2012, 115). 
the polis is self-sufficient and flourishing, they safeguard the freedom and wealth of all citizens, and thus, some important means for a good and happy life. Like peace and leisure, stability and prosperity are the best conditions for a fruitful life of contemplation, the good life of the scientist or philosopher. If a virtuous political life is able to reach these aims it contributes substantially to realizing this form of life, which, according to Aristotle's arguments in the Nicomachean Ethics, is even happier than the political life (ENX 7-9, 1177 a 12-1179 a 32).

According to Aristotle's classification of the political convictions of his time, for democrats worth $(\dot{a} \xi i a)$ "is freedom, for supporters of oligarchy it is wealth, for others it is noble birth, and for aristocrats it is virtue" ( $E N$ V 6, 1131 a 27-29). This section has demonstrated that for Aristotle the appropriate standard of worth and the most justified reason for claims in the distribution of political offices and honors is political virtue. Therefore, according to his classification he has to be categorized as a supporter of the aristocratic conception of distributive justice ${ }^{47}$. Furthermore, this section

Also Fred D. Miller comes to the conclusion that "Aristotle makes clear the superiority of the aristocratic theory": "In so far as the citizens are free, well-born, or wealthy, they can help to keep the polis in existence; but only in so far as they possess virtue can they directly contribute to its natural end. Therefore, the aristocratic theory is correct, and the virtuous have a just claim to political authority which is superior to that of other members of the polis. Furthermore, the aristocratic constitution is best [...] Thus the aristocratic theory of political rights is the authoritative theory of rights" (MILLER 1995, 127; cf. fn. 23). David Keyt distinguishes between an aristocratic and an Aristotelian conception of distributive justice. The latter has a standard of worth that includes not only virtue but wealth and freedom (KEYT 1991, 247, 259). To be sure, the Aristotelian standard of worth embraces wealth and freedom. But this is true for the aristocratic standard as well. As a consequence, there is no need to introduce an additional Aristotelian standard or conception of distributive justice. Keyt's interpretation leads to an inconsistency within the analysis of his paper. Keyt claims correctly that Aristotle's best polis is a "true aristocracy", which "embodies the Aristotelian conception of distributive justice" (ibidem, 260). As each constitution embodies its corresponding conception, it is only 
has made evident that for Aristotle every constitution contains or embodies a corresponding conception of distributive justice. As a consequence, Aristotle has to be classified in regard to his political convictions as a supporter of aristocracy.

Like for Plato, for Aristotle aristocracy is a constitution closely connected with kingship ( Pol. V 10, 1310 b 2-3, b 31-32; Rep. IV, 445 d). The fundamental principle of both constitutions is the virtue of the rulers. In both constitutions political power is distributed in proportion to virtue, which serves as both the aristocratic and the monarchic standard of worth. Apparently, both constitutions embody the same conception of distributive justice. But as kingship means an extremely unequal share in political power, it is only justified if the king distinguishes himself through outstanding virtue. For Aristotle, such extraordinary individuals cannot be found in contemporary Greece ( Pol. VII 14, 1332 b 16-27).

In Chapter 13 of Book III, Aristotle emphasizes that in the distribution of political power education and virtue are the most justified reasons for the political claim. As a consequence, in Chapters 14 through 17 he discusses mainly kingship and aristocracy and ponders which of these constitutions is best. After advancing some arguments in favor of aristocracy, Aristotle concludes that aristocracy is generally more desirable for the political communities than kingship (Pol. III 15, 1286 b 3-7). In the second chapter of Book IV, Aristotle refers back to these reflections: "Aristocracy and kingship have already been discussed (to

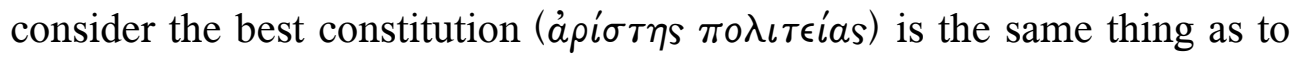
consider the two constitutions so named; since both are based on virtue provided with the necessary external means)" (Pol. IV 2, 1289 a 30-33). In this reference Aristotle understands both aristocracy and kingship as subspecies of the best constitution, which elucidates the close connection between these two constitutions.

sound to understand the conception contained in aristocracy as an aristocratic conception of distributive justice. 


\section{Aristocracy as the constitution of the best polis}

The arguments of this paper show that Aristotle supports both an aristocratic conception of distributive justice and aristocracy. This final section substantiates the thesis that the constitution of the best polis, which Aristotle outlines in Books VII and VIII, must be understood as a "true aristocracy", which embodies an aristocratic conception of distributive justice. Furthermore, the section gives arguments against interpretations that claim that Aristotle's "ideal constitution" is a mixed

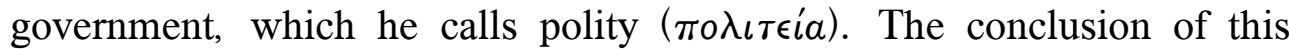
section and the whole paper is that Aristotle has to be understood as an aristocratic political thinker.

Aristotle approaches the question of the constitution of the best polis by first answering the question of the most desirable life. The specific characteristic of the best city, the polis according to our wishes ( $\kappa a \tau$ ' $\epsilon \dot{v} \times \eta^{\prime} \nu$ ), is that the citizens can lead the best and happiest life in it (Pol. VII 4, 1325 b 36). In order to achieve this goal, the citizens have to develop the specifically human virtues and become perfectly good and virtuous, which requires excellent natural dispositions, a first-rate education, and social conditions like wealth, leisure, and exemption from having to work. Apparently, the demands for being a member of the citizens of the best polis are very exacting. As a consequence, the best polis does not have many citizens.

The social structure of Aristotle's best polis has the shape of a pyramid. The top of the pyramid is constituted by a small leisure class of the good and virtuous citizens. The lower parts are composed of the vast majority of people who live in the polis as non-citizens. These people will be foreigners, resident aliens, and, as much as possible, slaves and barbarians. The non-citizens constitute the laboring class, which Aristotle divides into day-laborers, seamen, farmers, traders, and craftsmen. For Aristotle, the members of the laboring class are not parts of the polis, they 
are only indispensable conditions and means for the polis (Pol. VII 9, 1329 a 34-39).

Aristotle justifies the exclusion of the laboring class in view of the end of the polis. In order to live a good and happy life, one needs virtue. But the laboring class lacks the natural dispositions, education, or social conditions required to develop their virtues (Pol. VII 9, 1329 a 21-24). The laboring class has to serve the leisure class as a means for their good and happy life. Aristotle justifies this with the theory of natural slavery, which he develops in Book $\mathrm{I}^{48}$. He also argues that the members of the working class have a lower worth and are by nature designed for the

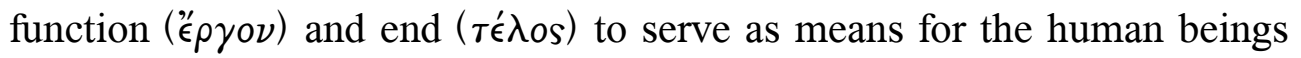
that have a higher rank in the natural order (cf. Knoll 2009, 200-01).

According to Aristotle's second definition, "A constitution is the order of a polis in respect to its various offices and the questions of how they are distributed, what the supreme power of the polis is, and what the end of every community is" (Pol. IV 1, 1289 a 15-18). The end of the best polis is undoubtedly the good and happy life, which requires that the citizens develop and practice their ethical and intellectual virtues in a political or theoretical life. This is an important reason why the constitution of the best polis cannot be understood as a polity. Aristotle declares more than once that the citizens of the polity, average Greek men, are far from being fully virtuous (Pol. III 7, 1279 a 39-1279 b 4; Pol. IV 11, 1295 a 2531). As a consequence, they do not possess the qualities which are required for citizenship in the best polis (cf. Schütrumpf 1980, 159). The best polis aims at a good and happy life and thus virtue. The best means to

In Book VII Aristotle refers several times directly or indirectly to his theory of natural slavery in Book I ( Pol. VII 2, 1324 b 36-41; Pol. VII 2, 1325 a 28-31; Pol. VII 14, 1333 a 3-11; Pol. VII 14, 1334 a 2; for a view of the barbarians that is more refined than the one exposed in Book I see Pol. VII 7). These references are an argument for the unity of the Politics. For a substantiation of the thesis that Aristotle justifies the rule of free citizens over natural slaves with his theory of distributive justice see KNOLL 2009, 149156. 
reach these goals is education. This explains why in his account of the best polis in Books VII and VIII Aristotle devotes a great deal of attention to education.

Aristotle does not say much about the concrete political institutions of the best polis. In order to determine its form of constitution, it is necessary to analyze his thoughts on how the political offices and the political power should be distributed. The citizens of the best polis are all supposed to be good, virtuous, and just. They are all equal and of the same kind. This is why they must all have the right to participate in the government of the polis. Aristotle points out that "for many reasons it is necessary for all to share in ruling and being ruled in turn. For equality means the same treatment of same persons, and a constitution that is not based on justice can hardly survive" (Pol. VII 14, 1332 b 25-29). According to the conception of distributive justice that is embodied in the constitution of the best city, all citizens have to participate in the government because they are all equally good and virtuous. Equal participation is not only required for reasons of justice but for reasons concerning the preservation of the polis. Linking up with his analysis of the change of constitutions in Book $\mathrm{V}$, Aristotle argues that an unjust constitution is often an instable one because it leads to sedition.

Aristotle's statement that "it is necessary for all to share in ruling and being ruled in turn" could be misunderstood as suggesting that the best constitution is a polity or a democracy ${ }^{49}$. But an analysis of how Aristotle understands equal participation rules out this interpretation. Shortly after this statement, he explains that it cannot be disputed that the rulers have to

This is a central misunderstanding of Nussbaum's interpretation of Aristotle's account of political participation. Nussbaum claims that Aristotle's "ideal city is a politeia" (2001, 147), and that he understands participation as a democratic form of participation (Nussbaum 1990; cf. 2000, 109). Mistakenly, she tries to support this thesis with Aristotle's statement quoted above (Pol. VII 14, 1332 b 25-27; cf. Knoll 2009, 26063). 
be better than their subjects. Referring back to what he had said some paragraphs before, Aristotle explains that nature made a distinction within the persons of the same kind by making some younger and some older. For the younger citizens it is appropriate to be governed, for the older ones to govern. This shouldn't offend the younger citizens as their turn to rule will come with the years (Pol. VII 14, 1332 b 35-42).

Aristotle correlates the two age-groups with two different qualities and two different political tasks. The first political task is to deliberate, to judge in law-courts, and to govern the polis. The second one is to protect the government against those who do not want to obey, and to defend the polis against attackers from outside. About the qualities of the two agegroups Aristotle declares that by nature the younger citizens have strength or vigor ( $\delta \dot{v} \nu a \mu \iota s)$, and the older ones prudence ( $\phi \rho o ́ \nu \eta \sigma \iota s)$. For Aristotle, the second political task is appropriate for the younger citizens, and the first one for the older ones. The constitution of the best polis entrusts both tasks to the same persons, however, not at the same stage of their life. Nevertheless, by allotting both tasks to every citizen it ensures an equal participation in the political life of the city. Aristotle justifies this distribution of political tasks with the aristocratic conception of justice:

But as by nature strength is found in the younger men and prudence in the older, such a distribution seems expedient and just; this mode of division also

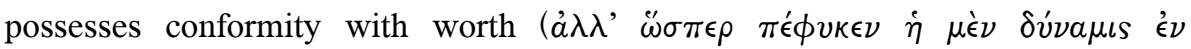

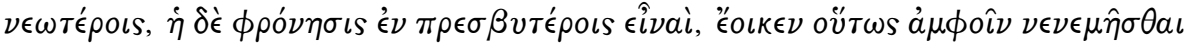

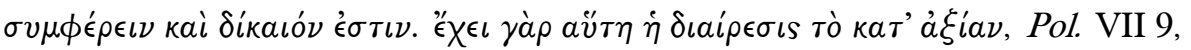
1329a 14-17).

In the best polis, the political offices and the supreme power are distributed according to worth. In its constitution, the appropriate standard of worth is primarily prudence ( $\phi \rho o ́ v \eta \sigma \iota s)$, which is the intellectual virtue 
that, combined with ethical virtues, constitutes political virtue ${ }^{50}$. This demonstrates that the constitution of the best polis embodies an aristocratic conception of distributive justice (cf. Keyt 1991, 260). Because, for Aristotle, each constitution embodies its corresponding conception of distributive justice, the constitution of the best polis has to be understood as an aristocracy. The quote above shows that the constitution of the best polis cannot be conceived of as a polity. Aristotle defines the polity as a mixture of democracy and oligarchy (Pol. IV 8/9, 1294 a 15-b 17). Analogously, the conception of distributive justice of the polity is a mixture of the standards of freedom and worth. The quote above demonstrates that these standards have little relevance in a just distribution of political offices.

Aristotle outlines the constitution of the best polis as an aristocracy. However, he considers the case that one citizen is distinguished through such extraordinary virtue that he surpasses all the others by far (Pol. VII 14, 1332 b 16-27). According to Aristotle's theory of justice, such an outstanding man would deserve to be allotted the supreme power and to be king. But as such men rarely exist, Aristotle's consideration is rather hypothetical than practical. However, as virtue is both the aristocratic and the monarchic standard of worth, and as aristocracy and kingship are closely connected constitutions, Aristotle holds them to be subspecies of the best constitution (Pol. IV 2, 1289 a 30-33).

The argument that the constitution of the best polis embodies an aristocratic conception of distributive justice is not the only reason that supports the thesis that it must be understood as an aristocracy. The constitution of the best polis also corresponds exactly to the features which Aristotle mentions in order to characterize a "true aristocracy". In Book IV Aristotle refers back to his account of aristocracy in Book III and talks

50 The citizens of the best polis do have the ethical virtues as well. For Aristotle, they are "absolutely just" ( Pol. VII 9, 1328 b 38). 
about "true aristocracy" as the "first and best constitution" ( Pol. IV 7, 1293 b 1-3, 19; cf. Pol. IV 2, 1289 a 30-33). He defines "true aristocracy" as a "constitution which is based on men that are absolutely the best according to their virtue, and not on good men only in relation to some other standard" (Pol. IV 7, 1293 b 3-5). Only in a "true aristocracy" the "good man is absolutely the same as the good citizen; in all other constitutions the good citizen is only good relatively to his own form of constitution" ( Pol. IV 7, 1293 b 5-7). In all other constitutions apart from "true aristocracy" the citizens are not distinguished through perfect virtue or the virtue of the perfect man. The virtue of a citizen has to be oriented towards his particular constitution. As there are many forms of constitutions, "it is evident that there is not one single virtue which is perfect virtue. But when we speak of a good man we mean that he possesses one single virtue which is perfect virtue" ( Pol. III 4, 1276 b 3134). The citizens of the best polis are all perfectly good and virtuous, and the constitution is based on these men. As soon as the citizens come of such an age that they may achieve prudence ( $\phi \rho o ́ \nu \eta \sigma \iota s)$, "the virtue of the citizen and ruler is the same as that of the best man". Aristotle points out that "the virtue of the good man and that of the good citizen is the same in the best polis". As the constitution of the best polis is based on the best and most virtuous men it corresponds exactly to the features which characterize a "true aristocracy" ( Pol. VII 14, 1333 a 11-12; Pol. III 18, 1288 a 38-39; Pol. VII 9, 1328 b 38-39).

The thesis that the constitution of the best polis is a "true aristocracy" can be supported as well by a third argument which is connected to the second. The goal or end of the constitution of the best polis is a good and happy life. This presupposes a focus on education in order to develop the virtues which are necessary for a good and happy life. A "true aristocracy" has exactly the same goal and the same requirement to develop virtue. In the context of his distinction of three kinds of 
aristocracy $^{51}$ in Book IV, Aristotle makes clear that aristocracies care about virtue and pay public attention to its generation (Pol. IV 7, $1293 \mathrm{~b}$ 12-13; cf. Pol. IV 2, 1289 a 30-33). The constitution of the best polis is a "true aristocracy" which embodies an aristocratic conception of distributive justice and which is based on the best men, whose outstanding virtues allow them to live a good and happy life.

As has been mentioned before, there are two opposing lines of interpretation of Aristotle's fundamental political convictions. An analysis of the mistaken interpretations, which hold Aristotle's "ideal city" to be a polity, shows that their representatives neglect Aristotle's distinction of four different tasks of constitutional theory, which he articulates at the beginning of Book IV of the Politics. The most important of these distinctions is the one between the task "to study which is the best constitution", and the task to "ascertain the form of constitution most suited to all cities" (Pol. IV 1, 1288 b 21-24, 33-35; cf. Knoll 2012, 133-135). While Aristotle executes the study of the best constitution in Books VII and VIII, he examines the polity mainly in Books IV-VI. The polity is most suited to all states because most cities at Aristotle's time were either democracies or oligarchies, and the polity is a stable mix of elements of these two unstable constitutions (Pol. IV 8/9, 1294 a 15-b $17)^{52}$. The neglect of Aristotle's distinction of these two tasks is already one cause for Werner Jaeger's division between an early "Urpolitik" (Books II, III, VII, and VIII), which contains Aristotle's "speculative outline", and the "empirical books" IV-VI, that were supposedly written later (Jaeger 1955, 275-282). If one takes seriously Aristotle's declaration that the same science has four different tasks, many

51 For Aristotle's distinction of three kinds of aristocracy and for the problem whether there are not, in fact, four kinds see IRRERA 2016.

Democracy and oligarchy are the main topic of Book VI. A large part of Book V is devoted to the analysis of the reasons why constitutions and especially why democracies and oligarchies change through seditions and revolutions. 
misunderstandings and supposed contradictions of the Politics disappear together with the need to postulate different strata of their origin. The same conclusion can be drawn from this analysis of the role of Aristotle's theory of distributive justice for his theory of constitutions. Distributive justice is a central topic of the Politics which is equally relevant for different books and for different aspects of Aristotle's theory of constitutions, and which must be regarded as one of the main factors that demonstre the unity of the Politics.

\section{Bibliography}

ARIstoteles (1965), Politik, nach der Übersetzung von F. Suseminl, hg. von N. TSOUYOPOLOUlOS und E. GRASSI, München.

Aristoteles (1973), Politik, übers. und hg. von O. GigON, München.

ARISTOTELIS (1954), Ethica Nicomachea, recognovit brevique adnotatione critica instruxit I. BYWATER ("Scriptorum Classicorum Bibliotheca Oxoniensis"), Oxford.

ARISTOTElis (1957), Politica, recognovit brevique adnotatione critica instruxit W.D. Ross ("Scriptorum Classicorum Bibliotheca Oxoniensis"), Oxford.

Aristotle (1991), Constitution of Athens, in: The Complete Works of Aristotle, ed. by J. BARNES, II, fourth printing, Princeton, N.J.

BARKER, E. (1959), The Political Thought of Plato and Aristotle, New York.

BAtes, C. A. Jr. (2003), Aristotle's. Kingship, Democracy, and the Rule of Law, Baton Rouge.

BERTELLI, L. (2016), Politica: questioni di composizione. É ancora praticabile 1" "ipotesi Jaeger?", in this issue of «ПНГН/FONS», 21-33.

BiEN, G. (1980), Die Grundlegung der politischen Philosophie bei Aristoteles, Freiburg-München.

Bleicken, J. (1994), Die athenische Demokratie, 2. Aufl., Paderborn-München-WienZürich.

BudDENSIEK, F. (2012), Gegenstand und Verfahren von Aristoteles' praktischer Philosophie, in: B. Zehnpfennig (ed.), Die „Politik“ des Aristoteles, Baden-Baden ("Staatsverständnisse"), 56-71.

Chuska, J. (2000), Aristotle's Best Regime. A Reading of Aristotle's Politics VII. 110, Lanham-Cumnor Hill. 
DEPEW, D. J. (1991), Politics, Music, and Contemplation in Aristotle's Ideal State, in: D. Keyt, F. D. Miller Jr. (eds.): A Companion to Aristotle's "Politics", Cambridge-Oxford, 346-380.

ELM, R. (1996), Klugheit und Erfahrung bei Aristoteles, Paderborn et. al.

EngISCH, K. (1971), Auf der Suche nach der Gerechtigkeit. Hauptthemen der Rechtsphilosophie, München.

Flashar, H. (1995), Die Platonkritik (I 4), in: O. HöFFE (ed.), Aristoteles: Die Nikomachische Ethik, ("Klassiker Auslegen" 23), II, Berlin, 63-82.

GeHRKE, H.-J. (1985), Stasis. Untersuchungen zu den inneren Kriegen in den griechischen Staaten des 5. und 4. Jahrhunderts, München.

GeHrKe, H.-J. (2001), Verfassungswandel (V 1-12), in: O. HöFFE (ed.), Aristoteles, Politik, ("Klassiker Auslegen" 23), Berlin, 137-150.

GORDON, J.-S. (2007), Aristoteles über Gerechtigkeit. Das V. Buch der Nikomachischen Ethik, Freiburg-München.

GUTSCHKER, Th. (2002), Aristotelische Diskurse. Aristoteles in der politischen Philosophie des 20. Jahrhunderts, Stuttgart-Weimar.

HAACKE, S. (1994), Zuteilen und Vergelten. Figuren der Gerechtigkeit bei Aristoteles, Wien.

HöFFE, O. (2001), Aristoteles, Politik, ("Klassiker Auslegen" 23), Berlin.

IRRERA, E. (2016), The Normative Significance of Aristocratic Constitutions in Aristotle's Politics, in this issue of «ПНГН/FONS», 98-122.

JAEGER, W. (1955), Aristoteles. Grundlegung einer Geschichte seiner Entwicklung, 2. veränderte Auflage, Berlin.

Keyt, D.-Miller, F. D. Jr. (1991), A Companion to Aristotle's "Politics", Cambridge-Oxford.

KeYt, D. (1991), Aristotle's Theory of Distributive Justice, in: D. Keyt, F. D. Miller Jr. (eds.), A Companion to Aristotle's "Politics", Cambridge-Oxford, 238-278.

KNOLL, M. (2009), Aristokratische oder demokratische Gerechtigkeit? Die politische Philosophie des Aristoteles und Martha Nussbaums egalitaristische Rezeption, München-Paderborn.

KNoll, M. (2010), Die distributive Gerechtigkeit bei Platon und Aristoteles, «Zeitschrift für Politik (ZfP)» 1, 3-30.

KNoll, M. (2011a), Die Politik des Aristoteles - eine unitarische Interpretation, «Zeitschrift für Politik (ZfP)» 2, 123-147.

KNoll, M. (2011b), Die Politik des Aristoteles - Aufsatzsammlung oder einheitliches Werk? Replik auf Eckart Schütrumpfs Erwiderung, «Zeitschrift für Politik (ZfP)» 4, 410-423. 
Knoll, M. (2012), Die Verfassungslehre des Aristoteles, in: B. ZEHNPFENNIG (ed.), Die "Politik" des Aristoteles, Baden-Baden ("Staatsverständnisse"), 126-143.

LISI, F. L. (2017), La justicia en la Politica [forthcoming].

Miller, F. D. Jr. (1991), Aristotle on Natural Law and Justice, in: D. KEYT, F. D. Miller Jr. (eds.), A Companion to Aristotle's "Politics", Cambridge-Oxford, 279306.

Miller, F. D. Jr. (1995), Nature, Justice, and Rights in Aristotle's "Politics", Oxford.

Mulgan, R. (1991), Aristotle's Analysis of Oligarchy and Democracy, in: D. KEYT, F. D. Miller Jr. (eds.), A Companion to Aristotle's "Politics", Cambridge-Oxford, 307-322.

NeSCHKE-HENTSCHKE, A. (2012), Recht und Gerechtigkeit, in: B. ZEHNPFENNIG (ed. ), Die "Politik" des Aristoteles, Baden-Baden ("Staatsverständnisse"), 106-125.

NeWman, W. L. (1887-1902), The Politics of Aristotle, II, Oxford.

Nussbaum, M. (1990), Aristotelian Social Democracy, in: R. B. Douglass, G. M. MARA, H. S. RICHARDSON (eds.), Liberalism and the Good, New York-London, 203-252.

Nussbaum, M. (1990), Nature, Function, and Capability: Aristotle on Political Distribution, in: G. Patzig (ed.), Aristoteles' "Politik". Akten des XI. Symposium Aristotelicum, Friedrichshafen-Bodensee, 25.8.-3.9.1987, Göttingen 1990, 152-186 (an earlier version of this paper was published in «Oxford Studies in Ancient Philosophy», suppl. vol., 1988, 145-184).

Nussbaum, M. C. (2000), Aristotle, Politics, and Human Capabilities: A Response to Antony, Arneson, Charlesworth, and Mulgan, «Ethics», CI 1 (October), 102-140.

Nussbaum, M. (2001), Love, Literature, and Human Universals: Comments on the Papers, in: A. Kallhoff (ed.), Martha C. Nussbaum: Ethics and Political Philosophy, Lecture and Colloquium in Münster 2000 ("Münsteraner Vorlesungen zur Philosophie" 4), Münster, 129-152.

Ottmann, H. (2001), Geschichte des politischen Denkens. Die Griechen. Von Platon bis zum Hellenismus, I-II, Stuttgart.

PATT, W. (2002), Grundzüge der Staatsphilosophie im klassischen Griechentum, Würzburg.

PAtzig, G. (1990), Aristoteles' "Politik". Akten des XI. Symposium Aristotelicum, Friedrichshafen-Bodensee, 25.8. -3.9.1987, Göttingen.

Polansky, R. (1991), Aristotle on Political Change, in: D. KeYT, F. D. Miller Jr. (eds. ), A Companion to Aristotle's "Politics", Cambridge-Oxford, 322-345.

RaWls, J. (1971), A Theory of Justice, Cambridge, Mass.

RICKERT, J. (1997), Gerechtigkeit und Gleichheit, Münster. 
Rowe, Ch. (1991), Aims and Methods in Aristotle's Politics, in: D. KeYT, F. D. Miller Jr. (eds.), A Companion to Aristotle's Politics, Cambridge-Oxford, 57-74.

Salomon, M. (1937), Der Begriff der Gerechtigkeit bei Aristoteles. Nebst einem Anhang über den Begriff des Tauschgeschäfts, Leiden.

SCHüTRUMPF, E. (1980), Die Analyse der Polis durch Aristoteles, Amsterdam.

SCHüTrumPF, E. (1991), Einleitung, in: Idem, Aristoteles, Politik Buch I. Einleitung, Übersetzung und Kommentar, Berlin-Darmstadt (Aristoteles, Werke in deutscher Übersetzung, ed. by H. Flashar, 9, Politik, Teil I).

SCHÜTRUMPF, E. (2001), Verfassungen und politische Institutionen, in: O. HöFFE (ed.), Aristoteles, Politik("Klassiker Auslegen" 23), Berlin, 121-136.

SCHÜTRUMPF, E. (2011), Aristoteles' Essays zur Verfassung - politische Grundkonzeptionen in der Politik in einer genetisch-analytischen Interpretation. Eine Erwiderung, «Zeitschrift für Politik (ZfP)» 3, 244-269.

SCHüTRUMPF, E. (2017), What is "just or right in distribution" in Aristotle's Nicomachean Ethics and Politics - too much justice, too little right, in: M. KNOLL, S. SNyder, N. ŞıMŞEK (eds.), New Perspectives on Distributive Justice [upcoming with De Gruyter].

Sternberger, D. (1984), Drei Wurzeln der Politik, Frankfurt am Main.

Thukydides (2002), Der Peleponnesische Krieg, ed. and transl. by G. P. LandmanN, Düsseldorf-Zürich.

TRUde, P. (1955), Der Begriff der Gerechtigkeit in der aristotelischen Rechts- und Staatsphilosophie, Berlin.

Walzer, M. (1983), Spheres of Justice. A Defense of Pluralism and Equality, New York.

Zehnpfennig, B. (2012), Die "Politik" des Aristoteles, Baden-Baden ("Staatsverständnisse"). 